\title{
EVALUATION OF THE GELATIN TECHNIQUE FOR THE PRESERVATION OF PHYTOPATHOGENIC FUNGI
}

\author{
AVALIAÇÃO DA TÉCNICA DA GELATINA PARA PRESERVAÇÃO DE FUNGOS \\ FITOPATOGÊNICOS
}

\author{
Igor Forigo BELOTI ${ }^{1}$; Breno Cezar Marinho JULIATTI ${ }^{2}$; Fernando Cezar JULIATTI $^{1,3}$ \\ 1. Universidade Federal de Uberlândia - UFU, Laboratório de Micologia e Proteção de Plantas - LAMIP, Uberlândia, MG, Brasil; \\ 2. Universidade Federal de Lavras, MG, Brasil; 3. Professor Titular da UFU, Pesquisador 1D do CNPq. juliatti@ufu.br
}

\begin{abstract}
The preservation methods for fungi have great importance in ex situ collections, representing important biological heritage, useful for mycologists and plant pathologists in several scientific works. However, there is a lack of studies for a suiTable and efficient preservation method for the different groups of fungi. Although, the most appropriate is the one that maintain, even after long periods, the original characteristics of culture: viability, sporulation and pathogenicity, excluding mutations and undesirable contamination. The choice will depend of the laboratory infrastructure, microorganism, objectives, preferences and knowledge of the researcher. We conducted this study inside the Laboratory of Mycology and Plant Protection (LAMIP) in UFU (Universidade Federal de Uberlândia), localized in Uberlândia (MG), Brazil. The objective was to evaluate the gelatin preservation method (17 cultures), never used before for phytopathogenic fungi. Other classical methods were concomitantly evaluated, such as sterile soil (68 cultures), resistant structures (Sclerotinia sclerotiorum) in $4{ }^{\circ} \mathrm{C}$ (10 strains) and mineral oil (31 cultures). We examined the time for maintaining the viability, sporulation and colonization in host tissues preserved in different dates. The gelatin method remained viability in 10 cultures; this method is suiTable for preservation of the genera and species: Colletotrichum spp., Septoria spp., Fusarium spp., F. moniliforme var. subglutinans, Macrophomina spp., Phomopsis spp. and Verticillium spp. The viability remained in 38 strains of sterile soil, three of mineral oil, and one strain of sclerotia reached a maximum preservation time in $4^{\circ} \mathrm{C}$ of four years.
\end{abstract}

KEYWORDS: Colonization. Pathogenicity. Preservation ex situ. Sporulation. Viability.

\section{INTRODUCTION}

Historically, the preservation of microorganisms began with the development of microbiology from the second half of the nineteenth century. Currently, the importance of preserving microorganisms has been observed in several relevant institutions as the American Type Culture Collection (ATCC), USA; the Deutsche Sammlung von Mikroorganismen und Zellkulturen (DSMZ), Germany; the International Mycological Institute (IMI), England; the Centraalbureau voor Schimmelcultures (CBS), Netherlands and the Japanese Collection of Microorganisms (JCM), Japan (URUBURU, 2003). According to January 2011 data, 585 culture collections in 68 countries were registered in the World Database Centre for Microorganisms (WFCC) and the number of fungi in these collections was calculated at 506,333 species (KARADUMAN et al., 2012).

These fungi cultures collections preserves a broad diversity of species, useful in discoveries in other areas such as biotechnology, functional, comparative and evolution genomics, bioprocesses and novel produtcs (BOUNDY-MILLS et al., 2016). Therefore, they should be available for the reproducibility of the results found by past searches and should keep unchanged; however, the storage of these microbial cultures is difficult and time consuming, needing the refinement of various techniques (KARADUMAN et al., 2012; SMITH; RYAN, 2012). A storage method that preserves culture viability is essential for research, into the modes of action of these pathogens (BASKARATHEVAN et al., 2009).

The preservation techniques can be divided according to the maximum time in which the cultures may remain without being handled: (a) short-term methods: periodic transfer; (b) mediumterm methods: mineral oil, sterile water, $-20^{\circ} \mathrm{C}$, silica gel desiccant, soil and filter paper; (c) longterm methods: lyophilization, cryopreservation at $80^{\circ} \mathrm{C}$ and liquid nitrogen $\left(-196^{\circ} \mathrm{C}\right)$. The chances of success of the method increases transferring the sample preserved in the culture media, with inoculation in original host every five years, for improvement of the routine work. This procedure reactive physiology of the fungus and can ensure maintenance of the original features for a further period of preservation in the laboratory; notwithstanding, there is a possibility of contamination and alteration of cultures (PIRES et al., 2012). 
The maximum duration of storage varies with each method and with the species preserved, but generally revolves in 10 years or less. The existence of a method that is able to preserve viability, sporulation and pathogenicity of as many genera and species as possible, will be more reliable, and more preferably, but isolated no technique has been successfully applied to all fungi (ABD-ELSALAM et al., 2010; APARECIDO; CAMILO, 2013). Several protocols have been developed and applied, however, most have not proven fully effective, because of the peculiarities of the cultures and even the characteristics of techniques; therefore it comes to explaining the combination of two or more methods in order to ensure the best recovery (GREEN, 2008).

The development of more suiTable methods for the preservation of microorganisms is of great importance to the culture collections and routine works. The varieties of methods reflect the lack of one satisfactory and convenient method for all organisms and perhaps the rugged individualism of research workers (ALFENAS; MAFIA, 2016). Despite the immense importance of microbial preservation, the research related to this area needs more attention. There are many possibilities of research available in the area of microbial preservation, but there is little interest in the optimization of preservation methods and the preserved cultures are currently limited to the culture collections or bioresource centers (BOUNDY-MILLS et al., 2016).

Thus, new methods of preservation, and even adaptations of methods used for other microorganisms should sought, citing as an example the gelatin method used for the preservation of phytopathogenic bacteria by Takatsu (1985). Thereby, this study aimed to evaluate the gelatin preservation method (17 cultures), never tested for phytopathogenic fungi and other classical methods: sterile soil (68 cultures), resistant structures (Sclerotinia sclerotiorum) in $4^{\circ} \mathrm{C}$ (10 fungi strains) and mineral oil (31 cultures), examining the time maintaining the viability, sporulation and colonization in host tissues preserved in different dates.

\section{MATERIAL AND METHODS}

\section{Gelatin method}

All preserved fungal cultures tested, are inside the Laboratory of Mycology and Plant Protection (LAMIP), in UFU (Universidade Federal de Uberlândia), Uberlândia (MG), Brazil. The evaluation of the preserved culture developed from August to Dezember, 2014. The procedure used to the gelatin method was an adaptation of the method of drying bacteria (TAKATSU, 1985) - there was no similar method in literature related for phytopathogenic fungi species.

The culture was developed on PDA media to fully cover the Petri dish (90 mm) (Figure 1A) for seven days, and the mycelium, covered successively with dextrose (5\%) and bacteriological gelatin (5\%) for one minute (each), promoting soaking of the mycelium and removing the excess. The mycelium was divided into approximately $1 \mathrm{~cm}^{2}$ fragments with a sterilized scalpel; these fragments were inserted under aluminum screens $\left(4 \mathrm{~cm}^{2}\right)$ inside plastic Petri dishes, previously perforated to allow gas exchange with silica gel (Figures $1 \mathrm{~B}$ and 1C). The Petri dishes, containing cultures fragments, were kept inside a plastic container with sterile silica (8 mesh) at its base (Figure 1D), properly sealed, preventing gas exchange with the atmosphere.

The sterilization of the plastic container and Petri dishes performed out in sodium hypochlorite solution $2.5 \%$ and $70 \%$ alcohol, exposed to ultraviolet light for 20 minutes in laminar flow. After drying for a period of 15 days, the culture fragments inserted in sterile paper envelopes and kept in refrigerator at $4^{\circ} \mathrm{C}$ (Figure 1E). In the Figure 2 , we can observe a simplified diagram for the method.

In LAMIP, 17 cultures of genera and species preserved in the gelatin method: Colletotrichum spp., Cladosporium spp., Septoria spp., Fusarium spp., $F$ moniliforme var. subglutinans, Cylindrocladium spp., Macrophomina spp., Phomopsis spp. and Verticillium spp. obtained in different hosts tissues and in different dates (Table 1).

\section{Sterile soil, Mineral oil and $4^{\circ} \mathrm{C}$}

Were preserved inside LAMIP, 68 cultures of genera and species in the sterile soil method: Fusarium spp., $F$. solani, $F$. oxyporum, $F$. oxysporum f. sp. lycopersici, $F$. oxysporum f. sp. vasinfectum, M. phaseolina, Rhizoctonia spp., $R$. solani, S. sclerotiorum, Sclerotium rolfsii and Verticilium spp. obtained in different hosts tissues and in different dates (Table 2). Preserved as sclerotia, the lab had ten fungi strains of $S$. sclerotiorum, stored in paper envelopes inside domestic refrigerator $\left(4^{\circ} \mathrm{C}\right)$. Different hosts provided the fungi strains, with different preservation dates (Table 2). 

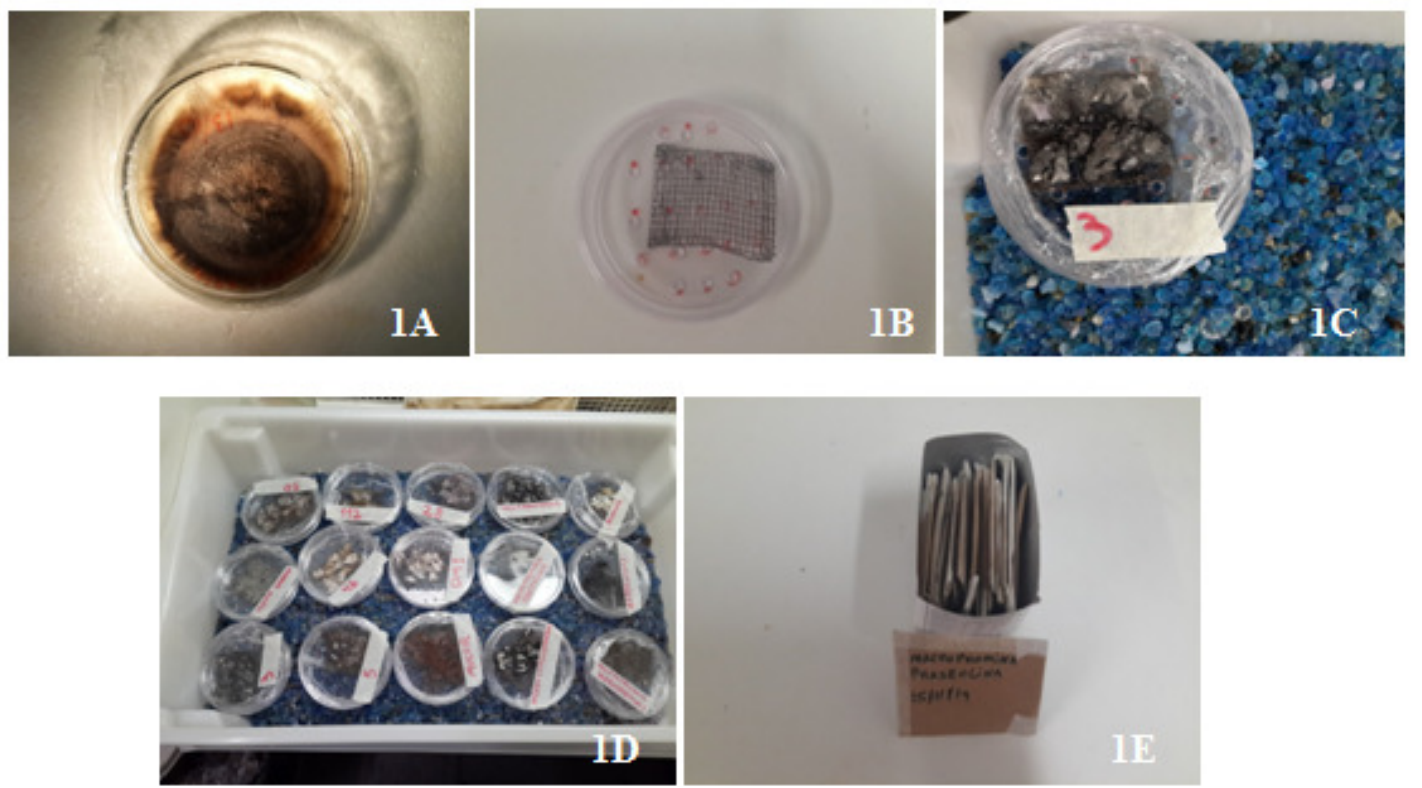

Figure 1. Procedures for the gelatin method for fungi preservation.

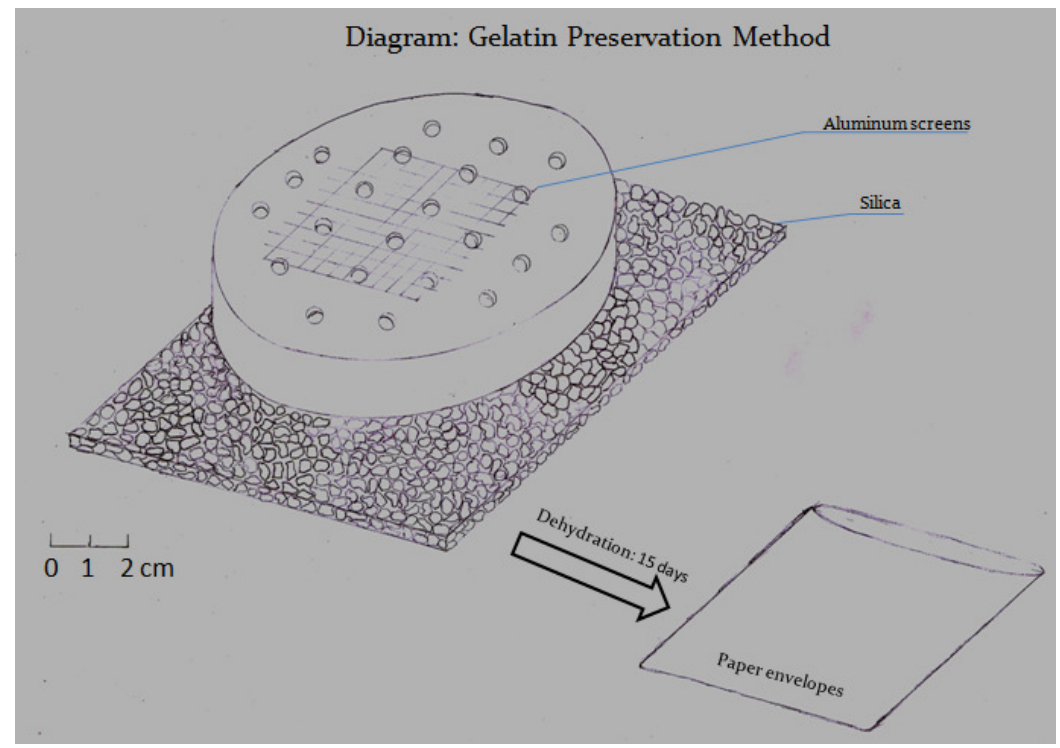

Figure 2. Simplified diagram for the gelatin method for fungi preservation.

Table 1. Fungi preserved in the Laboratory of Mycology and Plant Protection using the gelatin method.

\begin{tabular}{l} 
Code \\
\hline LAMIP 132A \\
LAMIP 132B \\
LAMIP 132C \\
LAMIP 133A \\
LAMIP 133B \\
LAMIP 134 \\
LAMIP 134A \\
LAMIP 134B \\
LAMIP 134C \\
LAMIP 135 \\
LAMIP 138 \\
LAMIP 140
\end{tabular}

Genera and especie
Colletotrichum spp.
Cladosporium spp.
Colletotrichum spp.
Septoria spp.
Septoria spp.
Colletotrichum spp.
Colletotrichum spp.
Colletotrichum spp.
Colletotrichum spp.
Fusarium spp.
Fusarim spp.
Fusarium spp.

Host

Passiflora sp.

Entry date

$08 / 10 / 1999$

Passiflora sp.

Passiflora sp.

$08 / 10 / 1999$

Passiflora sp.

$03 / 03 / 1998$

Passiflora sp.

$08 / 18 / 1998$

Coffea arábica

$02 / 10 / 1999$

C.arabica

$08 / 18 / 1998$

C.arabica

$09 / 06 / 2000$

C.arabica

$01 / 01 / 1999$

Passiflora sp.

(1/01/1999

Zingiber officinale

Gossypium hirsutum

$03 / 03 / 1998$

$04 / 26 / 2002$

$06 / 21 / 2004$ 


\begin{tabular}{|c|c|c|c|}
\hline LAMIP 167 & $\begin{array}{l}\text { F. moniliforme var. } \\
\text { subglutinans, }\end{array}$ & Ananas comosus & 06/01/2008 \\
\hline LAMIP 168 & Cylindrocladium spp. & N.I. * & 06/08/2008 \\
\hline LAMIP 169 & Macrophomina spp. & N.I. & $06 / 04 / 2008$ \\
\hline LAMIP 170 & Phomopsis spp. & N.I. & $04 / 06 / 2008$ \\
\hline LAMIP 171 & Verticillium spp. & N.I. & $06 / 04 / 2008$ \\
\hline
\end{tabular}

*N.I.: No Information

Table 2. Fungi preserved in the Laboratory of Mycology and Plant Protection using the sterile soil, mineral oil and $4^{\circ} \mathrm{C}$ methods.

\begin{tabular}{llll}
\hline \multirow{2}{*}{ Genera and specie } & \multicolumn{3}{c}{ Number of cultures tested } \\
\cline { 2 - 4 } & Sterile soil & Mineral oil & $4^{\circ} \mathrm{C}$ \\
\hline Fusarium spp. & 8 & 4 & - \\
F. solani & 2 & 1 & - \\
F. oxyporum & 9 & - & - \\
F. oxysporum f. sp. lycopersici & 19 & - & - \\
F. oxysporum f. sp. vasinfectum & 5 & - & - \\
F. moniliforme & - & 1 & - \\
Macrophomina phaseolina & 1 & - & - \\
Rhizoctonia spp. & 13 & - & - \\
R. solani & 1 & - & - \\
Sclerotium rolfsii & 4 & - & - \\
Sclerotinia sclerotiorum & 2 & - & 10 \\
Verticilium spp. & 4 & - & - \\
Cercospora zeae-maydis & - & 2 & - \\
Diaporthe phaseolorum & - & 3 & - \\
Pyricularia spp. & - & 3 & - \\
Colletotrichum spp. & - & 5 & - \\
C. gloeosporioides & - & 3 & - \\
Phyllosticta spp. & - & 1 & - \\
Phoma spp. & - & 1 & - \\
Cylindrocladium spp. & - & 1 & - \\
Drechslera oryzae & - & 2 & - \\
Phomopsis spp. & - & 2 & - \\
Ramularia spp. & - & 1 & - \\
Rhynchosporium spp. & - & 1 & - \\
\hline Total & 68 & 31 & 10 \\
\hline & & &
\end{tabular}

Were preserved 31 cultures in mineral oil of genera and species Cercospora zeae-maydis, Diaporthe phaseolorum, Pyricularia spp., Colletotrichum spp., C. gloeosporioides, Fusarium spp., F. moniliforme, F. solani, Phyllosticta spp., Phoma spp., Cylindrocladium spp., Drechslera oryzae, Phomopsis spp., Ramularia spp. and Rhynchosporium spp. obtained in different hosts tissues and in different dates (Table 2).

\section{Evaluation of the viability}

For evaluation of the fungi viability, were used test tubes $(12 \times 120 \mathrm{~mm})$ containing inclined potato dextrose agar (PDA) and six repetitions for each specie (repetition equals a tube). In each tube was inserted $3.5 \mathrm{~mL}$ of PDA $(\mathrm{pH} 5.5)$ with antibiotics $\quad(0.5 \quad \mathrm{mg} / \mathrm{L}): \quad$ chloramphenicol, streptomycin and ampicillin, to minimize bacterial contamination. Small fragments (approximately 0.2 $\mathrm{mm}^{2}$ ) inserted into the tube from the use of previously sterilized tweezers. After the inoculation, the tubes were sealed with hydrophobic cotton and kept in an acclimatized chamber $\left(20 \pm 2^{\circ} \mathrm{C}\right)$, with photoperiod of 12 hours, and viability assessed daily from the confirmation of mycelia growth on a stereomicroscope $(40 \mathrm{x})$ for a period of 15 days, with confirmation by an light microscope $(400 \mathrm{x})$.

For fungi viability detection, it was necessary to verify mycelial growth inside at least one of the tubes. When no mycelial growth was observed or there was development of fungal contaminants in all tubes, we used the Water Agar (WA) $2 \%, \mathrm{pH} 5.5$ in test tubes (3.5 mL per tube); 
three repetitions used for each specie (repetition equals a tube).

The evaluation of the viability of $S$. sclerotiorum strains occurred in semi-selective medium Neon-S (NAPOLEÃO et al., 2006). For disinfection, the sclerotia kepted one minute in distilled water, one minute in 50\% ethanol and three minutes in $1 \%$ sodium hypochlorite, and the excess removed using distilled water for one minute, and placed in tubes containing $3.5 \mathrm{~mL}$ of medium Neons. The tubes sealed with hydrophobic cotton and kept in a growth chamber BOD at $20^{\circ} \mathrm{C}$ in the dark for a period of 15 days, and the viability assessed only in the last day, with the formation of sclerotia and the characteristic change of color of the semiselective medium.

\section{Evaluation of the sporulation and colonization of \\ host tissues}

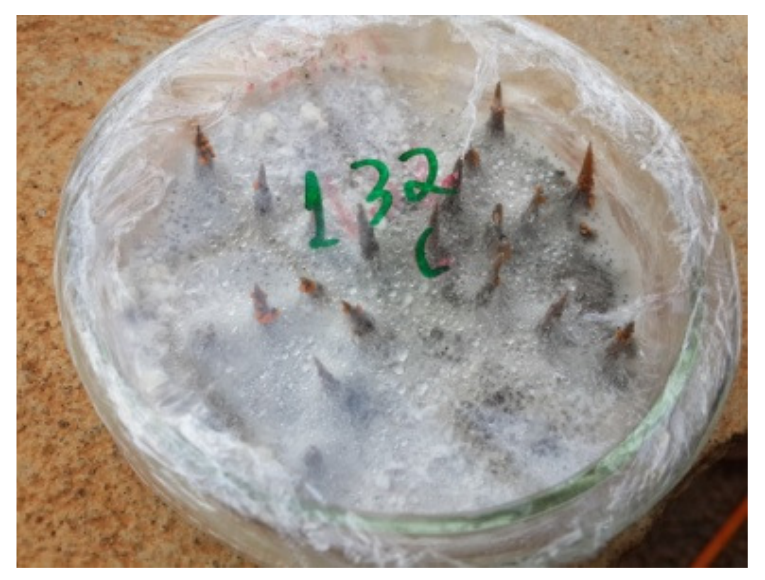

Figure 3. Sterile wooden sticks and Colletotrichum spp. mycelium growing on PDA media.

The disinfestation of tissues made through passage for one minute in each solution: $1.5 \%$ sodium hypochlorite, ethanol $50 \%$ and distilled water. Inoculation consisted in use of fungal structures presented in young and pure colonies, with help of sterelized scalpel and tweezers. The fruits/rhizomes inoculated and the control, were kept in climate chamber $\left(20 \pm 2^{\circ} \mathrm{C}\right)$, with 12 hours photoperiod and in sealed plastic bags for seven days.

\section{RESULTS}

Ten cultures preserved by the gelatin method, identified as viable, amid growing PDA and maintained the capacity of sporulation, except the genera Septoria spp. (Table 3). The fungi promoted colonization on the tested tissues, such as
The sporulation, regardless of the number of spores found, assessed from observation under a light microscope $(400 \mathrm{x})$, except for the isolates of $S$. sclerotiorum (sporulation occurs only in teleomorphic phase) and Rhizoctonia spp. (Class: Agaricomycetes - no production of spores). We observed the formation of sclerotia in $S$. sclerotiorum strains. To confirm the colonization, was conducted an inoculation in living host tissues as fruits and rhizomes, through the tissue perforation with sterile wooden sticks fragments, with the presence of growing mycelium (ALFENAS and MAFIA, 2007). The method consisted, in using sterile wooden sticks in Petri dishes containing PDA media. The culture that grew up in PDA, covered the wooden sticks, and after seven days used to inoculate the tissues (Figure 3). 
Table 3. Viable fungi observed in PDA media using the gelatin method for presenvation.

\begin{tabular}{|c|c|c|c|c|}
\hline Code & $\begin{array}{l}\text { Genera and } \\
\text { specie }\end{array}$ & Sporulation & Colonization & $\begin{array}{l}\text { Preservation } \\
\text { time }\end{array}$ \\
\hline $\begin{array}{l}\text { LAMIP } \\
132 \mathrm{C}\end{array}$ & $\begin{array}{l}\text { Colletotrichum } \\
\text { spp. }\end{array}$ & + & Passiflora sp & $\begin{array}{l}16 \text { years and } \\
40 \text { days }\end{array}$ \\
\hline $\begin{array}{l}\text { LAMIP } \\
133 \mathrm{~A}\end{array}$ & Septoria spp. & - & Passiflora $\mathrm{sp}$ & $\begin{array}{l}15 \text { years and } \\
241 \text { days }\end{array}$ \\
\hline $\begin{array}{l}\text { LAMIP } \\
133 \mathrm{~B}\end{array}$ & Septoria spp. & - & Passiflora sp & $\begin{array}{l}15 \text { years and } \\
62 \text { days }\end{array}$ \\
\hline LAMIP 135 & Fusarium spp. & + & Passiflora sp & $\begin{array}{l}16 \text { years and } \\
40 \text { days }\end{array}$ \\
\hline LAMIP 138 & Fusarium spp. & + & $\begin{array}{l}\text { Zingiber } \\
\text { officinale }\end{array}$ & $\begin{array}{l}11 \text { years and } \\
354 \text { days }\end{array}$ \\
\hline LAMIP 140 & Fusarium spp. & + & $\begin{array}{l}\text { Gossypium } \\
\text { hirsutum }\end{array}$ & $\begin{array}{l}9 \text { years and } \\
296 \text { days }\end{array}$ \\
\hline LAMIP 167 & $\begin{array}{l}\text { Fusarium } \\
\text { moniliforme } \\
\text { var. } \\
\text { subglutinans, }\end{array}$ & + & $\begin{array}{l}\text { Ananas } \\
\text { comosus }\end{array}$ & $\begin{array}{l}5 \text { years and } \\
321 \text { days }\end{array}$ \\
\hline LAMIP 169 & $\begin{array}{l}\text { Macrophomina } \\
\text { spp. }\end{array}$ & + & Glycine $\max$ & $\begin{array}{l}5 \text { years and } \\
318 \text { days }\end{array}$ \\
\hline LAMIP 170 & $\begin{array}{l}\text { Phomopsis } \\
\text { spp. }\end{array}$ & + & N.I. * & $\begin{array}{l}6 \text { years and } \\
11 \text { days }\end{array}$ \\
\hline LAMIP 171 & $\begin{array}{l}\text { Verticillium } \\
\text { spp. }\end{array}$ & + & N.I. & $\begin{array}{l}5 \text { years and } \\
318 \text { days }\end{array}$ \\
\hline
\end{tabular}

(-) No; (+) Yes; * (N. I.) No information

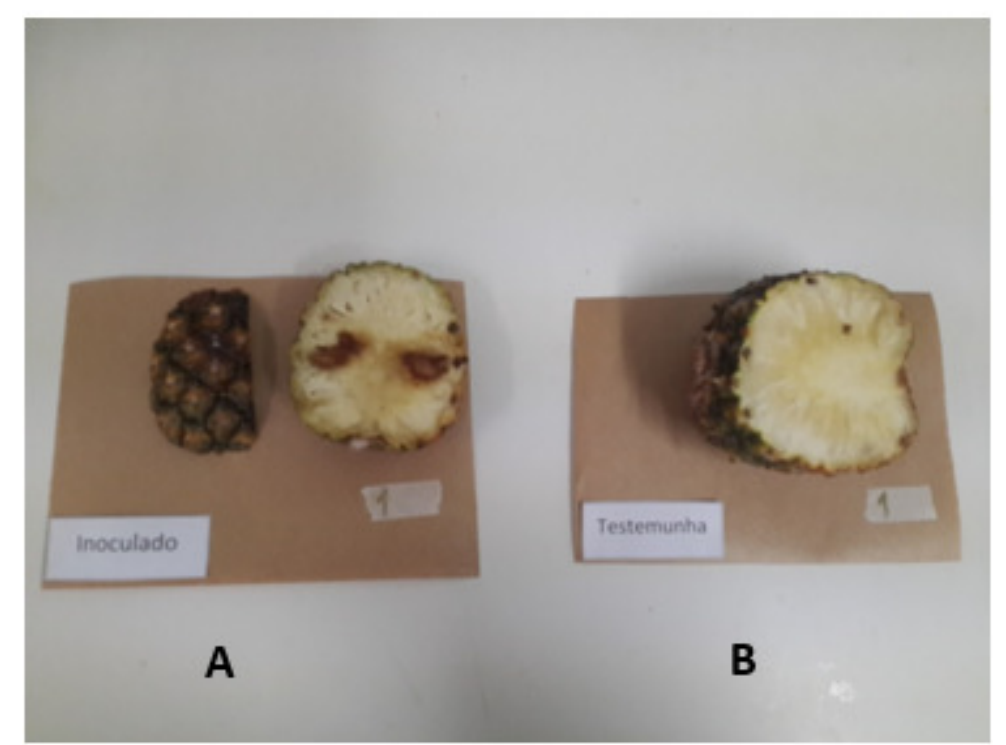

Figure 3. Fruit of Ananas comosus colonized by Fusarium moniliforme var. subglutinans, preserved using the wooden sticks method to inoculation. A. Colonized. B. Control.

Five cultures identified as viable, only on WA media: two of Fusarium spp. (maximum 11 years and 55 days); and three of Rhizoctonia spp. (maximum 37 years and 142 days) (Table 4). When preserved in mineral oil, 31 of the tested cultures, only three remained viable, identified in PDA: Colletotrichum spp. (11 years and 84 days); $F$. moniliforme (8 years and 168 days) and Phomopsis spp. (19 years and 226 days) (Table 4). All cultures maintained sporulation on PDA culture media. Only one fungal strain of $S$. sclerotiorum preserved in $4^{\circ} \mathrm{C}$ (about four years), remained viable, producing mycelium and resistance structures on semiselective medium Neon-S (Table 4). 
Table 4. Maximum viability of fungi cultures preserved by the sterile soil, mineral oil and $4^{\circ} \mathrm{C}$ methods.

\begin{tabular}{|c|c|c|c|c|c|c|}
\hline Code & $\begin{array}{l}\text { Genera and } \\
\text { specie }\end{array}$ & $\begin{array}{l}\text { Storage } \\
\text { method }\end{array}$ & Sporulation & Colonization & $\begin{array}{l}\text { Preservation } \\
\text { time }\end{array}$ & $\begin{array}{l}\text { Viability } \\
\text { in Culture } \\
\text { media }\end{array}$ \\
\hline $\begin{array}{l}\text { LAMIP } \\
044\end{array}$ & Fusarium ssp. & $\begin{array}{l}\text { Sterile } \\
\text { soil }\end{array}$ & - & $\begin{array}{l}\text { Passiflora } \\
\text { sp. }\end{array}$ & $\begin{array}{l}13 \text { years and } \\
40 \text { days }\end{array}$ & $\overline{P D A}$ \\
\hline $\begin{array}{l}\text { LAMIP } \\
014\end{array}$ & F. oxysporum & $\begin{array}{l}\text { Sterile } \\
\text { soil }\end{array}$ & + & Musa sp. & $\begin{array}{l}18 \text { years and } \\
328 \text { days }\end{array}$ & PDA \\
\hline $\begin{array}{l}\text { LAMIP } \\
013\end{array}$ & $\begin{array}{lr}\text { F. } & \text { oxysporum } \\
\text { f. } & \text { sp. } \\
\text { Vasinfectum }\end{array}$ & $\begin{array}{l}\text { Sterile } \\
\text { soil }\end{array}$ & + & $\begin{array}{l}\text { Gossypium } \\
\text { hirsutum }\end{array}$ & $\begin{array}{l}15 \text { years and } \\
66 \text { days }\end{array}$ & PDA \\
\hline $\begin{array}{l}\text { LAMIP } \\
043\end{array}$ & F. solani & $\begin{array}{l}\text { Sterile } \\
\text { soil }\end{array}$ & + & Glycine max & $\begin{array}{l}12 \text { years and } \\
343 \text { days }\end{array}$ & PDA \\
\hline $\begin{array}{l}\text { LAMIP } \\
073\end{array}$ & $\begin{array}{l}\text { Sclerotium } \\
\text { rolfsii }\end{array}$ & $\begin{array}{l}\text { Sterile } \\
\text { soil }\end{array}$ & $\mathrm{RE}^{*}$ & $\begin{array}{l}\text { Capsicum } \\
\text { аппиит }\end{array}$ & $\begin{array}{l}20 \text { years and } \\
33 \text { days }\end{array}$ & PDA \\
\hline $\begin{array}{l}\text { LAMIP } \\
068\end{array}$ & $\begin{array}{l}\text { Rhizoctonia } \\
\text { ssp. }\end{array}$ & $\begin{array}{l}\text { Sterile } \\
\text { soil }\end{array}$ & $\mathrm{A}^{* *}$ & N.I. *** & $\begin{array}{l}37 \text { years and } \\
142 \text { days }\end{array}$ & WA \\
\hline $\begin{array}{l}\text { LAMIP } \\
120\end{array}$ & $\begin{array}{l}\text { Colletotrichum } \\
\text { ssp. }\end{array}$ & $\begin{array}{l}\text { Mineral } \\
\text { oil }\end{array}$ & + & $\begin{array}{l}\text { Coffea } \\
\text { arabica }\end{array}$ & $\begin{array}{l}11 \text { years and } \\
84 \text { days }\end{array}$ & PDA \\
\hline $\begin{array}{l}\text { LAMIP } \\
161\end{array}$ & F. moniliforme & $\begin{array}{l}\text { Mineral } \\
\text { oil }\end{array}$ & + & $\begin{array}{l}\text { Saccharum } \\
\text { officinarum }\end{array}$ & $\begin{array}{l}8 \text { years and } \\
168 \text { days }\end{array}$ & PDA \\
\hline $\begin{array}{l}\text { LAMIP } \\
050\end{array}$ & $\begin{array}{l}\text { Phomopsis } \\
\text { spp. }\end{array}$ & $\begin{array}{l}\text { Mineral } \\
\text { oil }\end{array}$ & + & Solanum gilo & $\begin{array}{l}19 \text { years and } \\
226 \text { days }\end{array}$ & PDA \\
\hline $\begin{array}{l}\text { LAMIP } \\
175\end{array}$ & $\begin{array}{l}\text { Sclerotinia } \\
\text { sclerotiorum }\end{array}$ & $4^{\circ} \mathrm{C}$ & RE & Glycine $\max$ & $\begin{array}{l}\text { Approximately } \\
4 \text { years }\end{array}$ & Neon-s \\
\hline
\end{tabular}

\section{DISCUSSION}

Drying methods are technically simple and do not require expensive equipments. Furthermore, drying is a useful method of preservation for cultures that produce spores or other structures (FONG et al., 2000, NAKASONE et al., 2004). Some fungi can preserved easily and successfully for many years in dry, sterile soil or sand. Dormancy caused by dryness can take time to develop, however, morphological changes in some fungi have been recorded (NAKASONE et al., 2004).

Many soil fungi develop sclerotia, microsclerotia or other long-term survival propagules in culture as well as in nature. Preserving such structures, usually at $3^{\circ}-5^{\circ} \mathrm{C}$ is a good way to preserve fungal strains such as Magnaporthe, Phymatotrichum and Cylindrocladium, species that remain viable from about two to five years (SINGLETON et al., 1992). Example of long preservation in sterile soil is the fungus $V$. dahliae preserved 5 years (MELOUK, 1992). In our study, only six of 68 preserved fungi in sterile soil remained viable.

Bueno (2006) noted that after nine months of evaluation, there was a gradual decrease in the survival of the fungus in the refrigerator temperature $\left(5^{\circ} \mathrm{C}\right)$. The author has developed a methodology for the preservation of $S$. sclerotiorum resistance structures at $-20^{\circ} \mathrm{C}$ and stored such structures into $500 \mathrm{~mL}$ vials. After a year of preservation, all maintained their pathogenicity in the developed methodology. Singleton et al. (1992) suggests Sclerotinia genera can be preserved by periodic subcultures for a short period. In our study the preservation of $S$. sclerotiorum (strain LAMIP 175) remain viable at $4^{\circ} \mathrm{C}$ for approximately four years, suggesting that kind of preservation cannot exceed this period.

The mineral oil method advantages reported was the long viability of some fungi, the mites do not penetrate into the cultures and low cost. However, the strains do eventually lose viability, contamination with other fungi and bacteria is an occasional problem, and selection for mutants that can grow under adverse conditions may occur (ALFENAS; MAFIA, 2016).

Various genera was preserved in mineral oil for long periods in several collections, such as Colletotrichum spp. remained viable for up to 21 years, $F$. solani (25 years) and $V$. dahliae (2 years) at the Commonwealth Mycological Institute (CMI), UK (SMITH; ONIONS, 1983). In our study only three of 31 cultures remained viable, suggesting that it was not suiTable for the preserved fungi. 
Bueno (2006) suggest that the sclerotia preservation of $R$. solani produced in sandy-organic substrate was not promising because they did not remain viable after five months of evaluation. The results found in our study contrary this information, since the cultures remained viable in sterile soil for periods of maximum 37 years and 142 days, higher than those found in the literature. The viability of these genera identified only in the WA media. Preserve the sclerotia of S. sclerotiorum, after removal from diseased plants or culture media, at temperatures between 2 and $5^{\circ} \mathrm{C}$ (SINGLETON et al., 1992).

Maragon et al. (2003) proposes an adaptation of a preservation method: the dehydrated gelatin drops method (DGD). Twenty-seven strains of fungi of clinical interest were maintained by this method for a seven-year period at room temperature. None of the strains maintained by DGD were found to be contaminated by bacteria or other fungi and no apparent changes were observed in morphology or macroscopic features. This indicate that other gelatin method, such as the proposed by Takatsu (1985) can be use for vast genera of fungi.

\section{CONCLUSIONS}

The gelatin method was suiTable for preservation of the genera and species: Colletotrichum spp., Septoria spp., Fusarium spp., F. moniliforme var. subglutinans, Macrophomina spp., Phomopsis spp. and Verticillium spp. in an optimal work time for laboratory necessities (minimum 5 years).

It is not an expensive method, easy to reproduce, can be use in laboratories that do not have large financial resources to acquire equipments such as lyophilizer and deep-freezers, enabling the exchange of cultures between research institutions.

The viability remained in 38 cultures of sterile soil, three of mineral oil and sclerotia maximum time of preservation in $4^{\circ} \mathrm{C}$ was four years (one fungal strain).

\section{ACKNOWLEDGMENT}

To FAPEMIG for financial support.

RESUMO: Os métodos de preservação de fungos têm grande importância em coleções ex situ, representando importante patrimônio biológico, útil para micologistas e fitopatologista como suporte para vários trabalhos científicos. Não existe um método de preservação adequado e eficiente para os diferentes grupos de fungos, entretanto, o mais apropriado é o que mantém, mesmo após longos períodos, as características originais da cultura: viabilidade, esporulação e patogenicidade, excluindo mutações e contaminação indesejável. A escolha dependerá da infra-estrutura laboratorial, microorganismo, objetivos, preferências e conhecimentos do pesquisador. Este trabalho foi realizado no Laboratório de Micologia e Proteção Vegetal (LAMIP) da UFU (Universidade Federal de Uberlândia), localizado em Uberlândia (MG), Brasil. O objetivo foi avaliar o método de preservação da gelatina (17 culturas), nunca testado antes para fungos fitopatogêncios. Concomitantemente foram avaliados métodos clássicos, como solo estéril (68 culturas), escleródios (Sclerotinia sclerotiorum) em $4{ }^{\circ} \mathrm{C}$ (10 isolados) e óleo mineral (31 culturas). Avaliou-se a manutenção na viabilidade, esporulação e patogenicidade dos isolados. O método da gelatina manteve a viabilidade em 10 culturas, sendo adequado para a preservação dos gêneros e espécies: Colletotrichum spp., Septoria spp., Fusarium spp., F. moniliforme var. subglutinans, Macrophomina spp., Phomopsis spp. e Verticillium spp. A viabilidade foi mantida em 38 isolados em solo estéril, três isolados em óleo mineral e um apenas um isolado de escleródio atingiu um tempo máximo de preservação de quatro anos.

PALAVRAS-CHAVE: Colonização. Patogenicidade. Preservação ex situ. Esporulação. Viabilidade.

\section{REFERENCES}

ABD-ELSALAM, K. A.; YASSIN, M. A; MOSLEM, M. A; BAHKALI, A. H.; DE WIT, P. J. G. M.; MCKENZIE, E. H. C.; STEPHENSON, S. L.; CAI, L.; HYDE, K. D. Culture collection, the new herbaria for fungal pathogens. Fungal Diversity, Hong Kong, v. 45, n. 1, p. 21-32, 2010. https://doi.org/10.1007/s13225010-0063-z

ALFENAS, A. C.; MAFIA, R. G. Métodos em Fitopatologia. Viçosa. 1ª Ed. UFV. 382p, 2007.

ALFENAS, A. C.; MAFIA, R. G. Métodos em Fitopatologia. Viçosa. 2 ${ }^{a}$ Ed. UFV. 516p, 2016. 
APARECIDO, C. C.; PIRES, G. C. C.; FINATTI, D.; CAMILO, C. M. Preservação de micro-organismos a 80 C. Biológico, v. 74, p. 23-29, 2012.

APARECIDO, C. C.; CAMILO, C. M. Comparação de métodos para a preservação de fungos do gênero Colletotrichum em laboratório. Biológico, v. 75, p. 17-22, 2013.

BASKARATHEVAN, J.; JASPERS, M. V.; JONES, E. E.; RIDGWAY, H. J. Evaluation of different storage methods for rapid and cost-effective preservation of botryosphaeria species. New Zealand Plant Protection, v. 62 , p. 234-237, 2009.

BOUNDY-MILLS, K. L.; GLANTSCHNIG, E.; ROBERTS, I. N.; YURKOV, A.; CASAREGOLA, S.; DANIEL, H-M., GROENEWALD, M.; TURCHETTI, B. Yeast culture collections in the twenty-first century: new opportunities and challenges.Yeast, v. 33, 2016.

BUENO, C. J.; AMBRÓSIO, M. M. Q.; SOUZA, N. L. Preservação de fungos fitopatogênicos habitantes do solo. Summa Phytopathologica, v. 32, p. 42-50, 2006. https://doi.org/10.1590/S0100-54052006000100006

FONG, Y. K.; ANUAR, S; LIM, H. P., THAM, F. Y.; SANDERSON, F. R. A modified filter paper technique for long-term preservation of some fungal cultures. Mycologist, v. 4, p. 127-130, 2000.

https://doi.org/10.1016/S0269-915X(00)80090-7

GREEN, L. H. Practical handbook of microbiology. CRC: London, 2 ed. 874 pp, 2008.

KARADUMAN, A. B.; ATLI, B.; YAMAÇ, M. An example for comparison of storage methods of macrofungus cultures: Schizophyllum commune. Turkish Journal of Botany, v. 36, p. 205-212, 2012.

MARANGON, A. V.; BERTONI, T. A., KIOSHIMA, E. S., FALLEIROS DE PÁDUA, R. A.; VENTURINI, S.; SVIDZINSKI, T. I. Dehydrated gelatin drops: a good method for fungi maintenance and preservation. The New Microbiologica, v. 26, p. 305-309, 2003.

MELOUK, H. A. Verticililium. In: SINGLETON, L. L.; MIHAIL, J. D.; RUSH, C. M. (Ed.). Methods for research on soilborn phytopathogenic fungi. St. Paul: The American Phytopathological Society, 1992. P. 175-178.

NAKASONE, K. K.; PETERSON, S. W, JONG, S. C. Preservation and distribution fungal cultures. In: Mueller GM, Bills GF \& Foster MS (eds.) Biodiversity of Fungi, p. 37-47. Amsterdam: Elsevier Academic Press, 2004. https://doi.org/10.1016/B978-012509551-8/50006-4

NAPOLEÃO, R.; NASSER, L.; Carlos Lopes, C.; CAFÉ FILHO, A. Neon-S, novo meio para detecção de Sclerotinia sclerotiorum em sementes. Summa Phytopathologica, v. 32, p. 180-182, 2006.

https://doi.org/10.1590/S0100-54052006000200014

PASSADOR, M. M.; PIRES, G. C. C.; FINATTI, D.; APARECIDO, C.C.; FIGUEIREDO, M. B. Manutenção da viabilidade e patogenicidade de culturas mantidas na micoteca "Mário Barreto Figueiredo". Biológico, v. 72, p. 51-55, 2010.

PIRES, G. C. C.; APARECIDO, C. C., FINATTI, D.; Preservação em laboratório de fungos filamentosos por longos períodos de tempo. Biológico, v. 74, p. 9-16, 2012.

SINGLETON, L. L.; MIHAIL, J. D.; RUSH, C. M. Methods for research on soilborne phytopathogenic fungi. St. Paul: The American Phytopathological Society, 265 pp., 1992.

SMITH, D.; ONIONS, A. H. S. A comparison of some preservation techniques for fungi. Transactions of the British Mycological Society, v. 81, p. 535-540, 1983. https://doi.org/10.1016/S0007-1536(83)80122-3 
SMITH, D.; RYAN, M. Implementing best practices and validation of cryopreservation techniques for microorganisms. The Scientific World Journal, Cairo, 2012.

TAKATSU, A. Preservação de bactérias fitopatogênicas pelo método de dessecação. Universidade de Brasília. Departamento de Biologia Vegetal, 5pp., 1985.

URUBURU, F. 2003. History and services of culture collections. International Microbiology, v. 6, p. 101103, 2003. https://doi.org/10.1007/s10123-003-0115-2 